\title{
NGOs and West European Migration Governance (186os until Present): Introduction to a Special
}

\section{Issue}

\author{
Marlou Schrover \\ Leiden University \\ m.l.j.c.schrover@hum.leidenuniv.nl \\ Teuntje Vosters \\ Leiden University \\ t.s.vosters@hum.leidenuniv.nl \\ Irial Glynn \\ Leiden University \\ i.a.glynn@hum.leidenuniv.nl
}

\begin{abstract}
Social and political scientists are involved in an extensive but inconclusive debate about the role of international nongovernmental organisations (NGOs) in European migration governance. The European Union (EU) and NG Os work under the assumption that NGOs are crucial to migration governance and yet the role of NGOs is not clear. The EU has invested time and money in its attempts to involve NGOs more actively in migration governance, but it does so without much knowledge of how NGOS in the past have influenced migration governance, and thus with no idea if the current investments are worthwhile. In this article, which is the introduction to the special issue on this subject, we take a closer look at the NGOs involved in West European migration in the period from the 186os until the present day in order to understand the changing role of NGOs in migration governance in Europe. Providing moral, logistical and expert authority in a purportedly impartial way, NGOs have added a dimension to migration governance that states cannot replicate. As a result, the number of NGOS has gradually increased and at times their influence has become significant. However, in providing a chronology of the involvement of NGOs in migration governance, we show that their influence on migration governance policies and practices has not been linear. During some windows of opportunity (e.g. in the immediate years following the First and Second World Wars and the Cold War), NGos became more prominent and
\end{abstract}


effective, while at other times (e.g. the 1930s), their importance waned. The presence and capacity of NGOs to contribute to migration governance depended on whether states, and increasingly after 1945, intergovernmental organisations such as the UN, needed them to further their own interests or to fulfil a role that they could not play.

\section{Keywords}

migration governance - NGOS - types of authority

This special issue is the result of an interdisciplinary conference at which experts discussed the significance, position, and contribution of non-state actors to migration governance. ${ }^{1}$ In the late 1990s, dissatisfaction with the explanatory power of regime theory and its rationalist origins led to the introduction of the broader concept of migration management, and an interest in politics beyond the state. ${ }^{2}$ More recently, management was replaced by governance to include civil society (of which NGOs - nongovernmental organisations are part), hoping that this would help change migration into an orderly and predictable phenomenon. ${ }^{3}$ Governance is defined as the processes of governing by governments and other organisations (including NGOS, and firms), through laws, norms, and discourse. ${ }^{4}$ It refers to the process of interaction and decision-making among actors. ${ }^{5}$ The conference, tapping into this debate,

1 In 2016 at Leiden University.

2 A. Betts (eds), Global migration governance (Oxford 2011).

3 F. Crépeau and I. Atak 'Global migration governance avoiding commitments on human rights, yet tracing a course for cooperation', Netherlands Quarterly of Human Rights 34:2 (2016) 113-146.

4 B. Gosh (ed), Managing migration: Time for a new international regime? (Oxford 200o); D. Lewis and P. Opoku-Mensah, 'Policy arena moving forward research agendas on international NGOs: theory, agency and context', Journal of International Development 18 (2006) 665-675; M. Geiger and A. Pécoud, 'The new politics of international mobility: Migration management and its discontents', IMIS Beiträge 40 (2012) 11-24; M. Czaika and H. de Haas, 'The effectiveness of immigration policies', Population and Development Review 39:3 (2013) 487-508; A. Betts, 'The global governance of crisis migration', FMR 45 (2014) 76-79; M. Geiger and A. Pécoud, 'International organisations and the politics of migration', Journal of Ethnic and Migration Studies 40:6 (2016) 865-887.

5 M. Bevir, Governance: A very short introduction (Oxford 2013). 
showed that there was a lack of historical and empirical work on NGOs, which this special issue attempts to fill. In the sections below, the articles of this special issue are put into the context of the broader debate. We aim to historicise the field of migration governance, investigate the effectiveness of NGOS, and their relation to IGOs (inter-governmental organisations) and the state. Although the articles in this issue underline our aim to historicise, they do show an imbalance because they focus on Western Europe, and do not cover the period from the 1970s to the 1990s (although this introduction does include these decades). We hope future studies will remedy that. The articles in this issue are about the role of NGOS. NGOs can have influence on policies and their implementation because they claim to represent the migrants they work for. However, most of the people working for NGOs are not migrants, and analysing the role of NGOs is not the same as studying the voice of the immigrants. Exploring migrant experiences of NGOs is a related but separate issue.

In this article and special issue, we look at how, when and why the role of NGOS in migration governance in Europe changed. There is a large number of publications that define NGOs, and they introduce a myriad of sub-labels and different typologies of NGOS. ${ }^{6} \mathrm{NGO}$ are defined here as organisations that are not established by a government or by intergovernmental agreement. This broad definition includes non-state actors that are not included in this issue such as multinational corporations, schools and universities, political parties, churches, rebel groups, trade unions and sports clubs. We included in this introduction NGOs that work in the field of migration, and which seek to promote specific goals (such as migrant protection) or to influence policies (for instance liberalising migration restrictions).

In this article, we use the term NGO for the whole period under study, although the term was only coined in 1945, with the creation of the United Nations (UN). The UN granted selected international NGOs observer status at its assemblies and meetings, as the League of Nations (LoN 1920-1946) had done for NGOs, which were at that time called private relief or voluntary organisations. Later, the term NGO acquired a broader meaning and included also organisations that did not have observer status. IGOs are organisations established by official treaties to work on areas that several states have a shared interest in tackling.

There are millions of NGOs worldwide, most of which operate at the local or national level. The current edition of the Yearbook of International Organizations, which lists NGOs that operate internationally, contains over

6 D. Hilhorst, The real world of NGOs: Discourses, diversity and development (London 2003). 
75,000 entries on international NGOs and IGOs (half of these are active, the rest are dormant). ${ }^{7}$ Migrants in this issue refers to all categories of migrants, including refugees. Policy makers, as a rule, distinguish between four major categories of migrants: refugees, labour migrants, family migrants and colonial migrants. ${ }^{8}$ This categorisation is related to laws and regulations (e.g. in the case of refugees to the ${ }^{1951}$ Refugee Convention). The literature frequently focusses on one category only (mostly refugees), but NGOs and IGOs were and are simultaneously active on behalf of migrants in all four categories. ${ }^{9}$ In addition NGOs spend a lot of time and money on, and have derived much of their authority from activities that cut across the four categories: saving children, fighting the trafficking of women, or protesting statelessness. It is rather common for policy makers and the people involved - to make a distinction between refugees and other migrants. This dates back to well before the introduction of the $195^{1}$ Refugees Convention, as Shaw shows..$^{10}$ Refugees were and are perceived as different from other migrants because they are seen as deserving support, and states that provide this support claim to be democratic, civilised and humane. In practice, however, the lines between the categories were and are not always so sharp, as has been recognised in recent debates scrutinising the artificial boundaries between categories. ${ }^{11}$

This introduction provides a helicopter view of the history of NGO activity in West-European migration governance in the period from the 186 os until the present day in all four policy domains, as well as those cutting across domains. We argue that the changing role of NGOs can only be explained if the activities of NGOS are studied alongside and in interaction with the actions of IGOs. We focus on Western Europe because that is the home-base of some of

7 Published since 1910 and now online http://www.uia.org/yearbook; http://www.staff.city .ac.uk/p.willetts/NGOS/NGO-HOME.HTM

8 M. Schrover, 'Labour migration', in: M. van der Linden and K. Hofmeester (eds), Handbook Global History of Work (Oldenbourg 2017) 443-478.

$9 \quad$ P. Gatrell, 'The World Wide Web of Humanitarianism, NGOs and population displacement in the third quarter of the twentieth century', European Review of History 23:1-2 (2016) 101-115.

10 C. Shaw, Britannia's embrace: Modern humanitarianism and the imperial origins of refugee relief (Oxford and New York 2015).

11 UNHCR, Refugee Protection and Mixed Migration: a 10-Point Plan of Action, January 2007, available at: http://www.unhcr.org/protection/migration/4742a3ob4/refugee -protection-mixed-migration-10-point-planaction. H. Crawley and D. Skleparis, 'Refugees, migrants, neither, both: categorical fetishism and the politics of bounding in Europe's "migration crisis", Journal of Ethnic and Migration Studies 44:1 (2018) 48-64. 
the largest and oldest NGOs, although they were also active outside Europe. ${ }^{12}$ The focus on Europe is also explained by current debates on the role of NGOs in European migration governance. ${ }^{13}$ The European Union (EU), other IGOs, national states, and NGOs are convinced that NGOs do, can and should play a role in migration governance. The EU and UN increasingly involve NGOs in policy making and implementation, although the academic debate on the role of NGOs in migration governance is inconclusive. ${ }^{14}$

The interaction between states and NGOs works in two ways. On the one hand, NGOs and IGOs depend on states for financial support, and for the ratification and implementation of treaties. ${ }^{15}$ Since NG Os also sometimes campaign against state policies this dependency is to some degree paradoxical. ${ }^{16}$ On the other hand, states need organisations to do what they cannot do themselves. ${ }^{17}$ Part of the literature on global governance assumes that the power of NGOs has increased at the expense of state sovereignty. However, other scholars argue that the interaction should not be treated in terms of opposites: states provide funding to NGOS, and they leave space for NGOs to operate. ${ }^{18}$ This makes the interactions more dependent than discordant. ${ }^{19}$

The position states take differs per country. In Sweden, for instance - as Frohnert shows in this issue - the state excluded NGOs from assisting migrants

12 T. Davies, NGOs: A new history of transnational civil society (Oxford 2013); F. Käser, 'A civilized nation: Japan and the Red Cross 1877-1900', European Review of History 23: 1-2 (2016) 16-32; K. O'Sullivan, M. Hilton and J. Fiori, 'Humanitarianisms in context', European Review of History 23 1-2 (2016) 1-15.

13 B. Kohler-Koch, "The three worlds of European civil society. What role for civil society for what kind of Europe?', Policy and Society 28 (2009) 47-57.

14 Gosh (ed), Managing migration; Geiger and Pécoud, 'The new politics of international mobility'; Czaika and De Haas, 'The effectiveness of immigration policies'.

15 A. Florini, Third force: the rise of transnational civil society (Washington 2000); S. Khagram, J.V. Riker and K. Sikkink, 'From Santiago to Seattle: Transnational advocacy groups restructuring world politics', in: S. Khagram, J.V. Riker and K. Sikkink (eds) Restructuring world politics: Transnational social movements, networks, and norms (Minnesota 2002) 3-23; Geiger and Pécoud, 'International organisations'.

16 M. Hilton, J. McKay, N. Crowson and J-F. Mouhot, The Politics of expertise. How NGos shaped modern Britain (Oxford 2013).

17 N. Nikolova, 'Immigration and refugee policies of Bulgaria as part of the accession process to the EU', Der Donauraum 49:1-2 (2009) 33-43; K. O'Sullivan, 'Humanitarian encounters: Biafra, NGOs and imaginings of the Third World in Britain and Ireland, 1967-70', Journal of Genocide Research 16:2-3 (2014) 299-315.

18 O.J. Sending and I.B. Neumann, 'Governance to governmentality: Analyzing NG Os, states and power', International Studies Quarterly 50 (2006) 651-672.

19 G. Mann, From empires to NGOs in the West African Sahel: The road to non-governmentality (Cambridge 2015). 
from 1945 to the early 1990s. In the 1990s, the arrival of large numbers of asylum seekers from (former) Yugoslavia caused the Swedish state to seek assistance from NGOS. In southern European countries, by contrast, the state has continuously turned to NGOs for help with migration governance. ${ }^{20}$ In recent years, the EU has relied heavily upon NGOs for the implementation of policies in the newer member states in part because it lacks the instruments to enforce policies without this assistance. ${ }^{21}$

NGOS, in our view, have three types of authority, which enable them to play a role in shaping policies and determining practices: expert authority, moral authority, and logistical authority. ${ }^{22} \mathrm{NGO}$ have expert authority when they know the rules and laws, and have access to statistics (e.g. number of refugees). NGOS have moral authority when they can claim the moral high ground (by fighting discrimination, protecting women and children, or claiming neutrality). NGOs have logistical authority when they, for instance, have proven that they can organise emergency relief (fast) or mobilise people. We argue that these types of authority (expert, moral, and logistical) are policy-domain specific, and depend on the size, age and status of the NGOs. At one end of the scale are large and established organisations which not only deal with migrant issues, but are also, for instance, anti-poverty or development aid organisations. They, as a rule, have all three types of authority. At the other end of the scale are small NGOs which have developed a particular niche within migration policy and which have one type of authority only. Vermeulen and Gnes in this issue connect authority to legitimacy and argue that it is crucial to understand the relationship between organisations and the environment in which they

20 M. Albahari, Crimes of peace: Mediterranean migrations at the world's deadliest border (Philadelphia 2015).

21 A. Warleigh, “Europeanizing” civil society: NGOs as agents of political socialization', Journal of Common Market Studies 39:4 (2001) 619-639; I. Sudbery, 'Bridging the legitimacy gap in the EU: can civil society help to bring the Union closer to its citizens?', Collegium 26 (2003) 75-95; I. Bache and S. George, Politics in the European Union (Oxford 2006); Geiger and Pecoud, The new politics of international mobility; Betts, 'The global governance'; K. O'Sullivan, 'A “Global nervous system": The rise and rise of European Humanitarian NGOs, 1945-1985', in: M. Frey, S. Kunkel and C. Unger (eds), International organizations and development, 1945-199o (Basingstoke 2014) 196-219.

22 M. Weber, Economy and society: An outline of interpretive sociology (Berkeley 1978); M. Barnett and R. Duvall, 'Power in international politics', International Organization 59:1 (2005) 39-75; M. Barnett and T.G. Weiss, Humanitarianism in question: Politics, power, ethics (Cornell 2008) 38; E.M. Uçarer, 'Tempering the EU? NGO advocacy in the area of freedom, security, and justice', Cambridge Review of International Affairs 27:1 (2014) 127-146. 
operate. Their article answers the important question: why do some organisations adapt, change goals, and branch out while others do not?

We define NGOs as having (measurable) influence on migration governance when they are given a role in negotiations (as part of committees, delegations and advisory groups), provide advice, co-draft treaties, and when others use their contacts, networks, statistics and expertise. ${ }^{23}$ Their influence becomes apparent when their ideas, concepts and proposals are incorporated into conventions and guidelines, when their claims, arguments, strategies and examples are adopted and reproduced by others, and when their proposals are translated into the practice of law. ${ }^{24}$ Since profit making is not the primary goal of NGOs, financial gains are not an indicator, although the amount of money that NGOS attract over time provides an indication of their sustainability. ${ }^{25}$ NGOs exert influence when they organise social and political arrangements: educating the public, empowering people, constructing networks and monitoring agreements. ${ }^{26}$ Even weak or non-ratified treaties that NGOs contribute to can become influential if they launch ideas that later become important. ${ }^{27}$

Part of the literature on NGOS is descriptive, has strong moral overtones, is a-historical and policy driven. ${ }^{28}$ In the last 15 years, research on the history of humanitarianism has increased. ${ }^{29}$ However, most of that literature is not

23 S. Ahmed and D.M. Potter, NGos in international politics (Colorado 2013).

24 Florini, Third Force; C. Kaunert, S. Léonard and U. Hoffmann, 'Venue-shopping and the role of Non-Governmental Organisations in the development of the European Union asylum policy', Comparative Migration Studies 1:1 (2013) 179-200; Khagram, Riker and Sikkink, Restructuring world politics.

25 M. Edwards and D. Hulme (eds), Beyond the magic bullet: NGO performance and accountability in the post Cold-War world (London 1995).

26 T. Risse-Kappen, 'Let's argue!": Communicative action in world politics,' International Organization 54:1 (2000) 1-39.

27 R.M. Price, 'Transnational civil society and advocacy in world politics', World Politics 55:4 (2003) 579-6o6. See also S. Heim, 'International refugee policy and Jewish immigration under the shadow of National Socialism', in: F. Caestecker and B. Moore (eds), Refugees from Nazi Germany and the liberal European states (Oxford 2010) 17-47.

28 Lewis and Opoku-Mensah, 'Policy arena moving forward research agendas'; Crépeau and Atak 'Global migration governance'.

29 B. Taithe and J. Borton, 'History, memory and "lessons learnt" for humanitarian practitioners', European Review of History 23: 1-2 (2016) 210-224; J. Paulmann, 'Conjunctures in 
about non-state actors. ${ }^{30}$ There are exception such as for instance Davies with his long history of transnational civil society, of which NGOs are part. ${ }^{31}$ Similarly, O'Sullivan, Hilton and Fiori recently bucked the trend by describing the global rise of non-state humanitarianism over the last 150 years. ${ }^{32}$ Also the literature on the history of refugee migration does pay attention to states, international organisations, and NGOs, and there are some valuable historical studies on specific NGOs. ${ }^{33}$

Several authors have described the waxing and waning of NGOS and their activities over time. ${ }^{34}$ Authors have also tried to identify key moments of change. The Universal Declaration of Human Rights in 1948 is seen as key, but in practice human rights were rarely referenced until decolonisation took place. According to Epp, a rights revolution occurred in the 1970s, which resulted in an increase in the number of NGOS. ${ }^{35}$ Moyn notes that international lawyers began to embrace human rights in the 1970s as 'a morally attractive mechanism for social change. ${ }^{36}$ In addition, Bradley argues that a range of non-state actors including lawyers, filmmakers, statisticians, grassroots activists and NGOS like Amnesty International made human rights part of the public and political

the history of international humanitarian aid during the twentieth century', Humanity: A Journal of Human Rights, Humanitarianism and Development 4:2 (2013) 215-238.

C. Lancaster, Foreign aid, diplomacy, development, domestic policies (London 2007); T.B. Olesen, H.O. Pharo and K. Paaskesen (eds), Saints and sinners: Official development assistance and its dynamics in a historical and comparative perspective (Oslo 2013).

31 Davies, NGOS.

32 O'Sullivan, Hilton and Fiori, 'Humanitarianisms in context', 2.

33 M.R. Marrus, The Unwanted: European refugees in the twentieth century (Oxford 1985); C. Moorehead, Dunant's dream: War, Switzerland and the history of the Red Cross (London 1998); G. Loescher, The UNHCR and world politics: A perilous path (Oxford 2001); P. Gatrell, The making of the modern refugee (Oxford 2013); P. Orchard, A right to flee: Refugees, states, and the construction of international cooperation (Cambridge 2014). On specific organisations see: L. Venturas, et al (ed), International 'migration management' in the Early Cold War: The Intergovernmental Committee for European Migration (Peloponnese 2015); F. Kind-Kovács, 'The Great War, the child's body and the American Red Cross', European Review of History: Revue européenne d'histoire 23:1-2 (2016) 33-62.

34 M. Mazower, 'The end of civilization and the rise of human rights: The midtwentieth-century disjuncture', in: S. Hoffmann (ed), Human rights in the twentieth century (Human Rights in History) (Cambridge 2010) 29-44; Akira Iriye, Global community. The role of international organizations in the making of the contemporary world (Berkeley, Los Angeles, London 2002).

35 C. Epp, The rights revolution (London 1998); Hoffmann (ed), Human rights in the twentieth century.

36 S. Moyn, The last Utopia (Cambridge, Mass 2010) 179. 
discourse. However, the development of human rights is in no way a linear narrative, but is instead 'messy and complex.' ${ }^{37}$ Davies, who has analysed the full span of global civil society organisations of which humanitarian NGOs are part, counters the idea of linear growth, and the premise of a present day transnational civil society of unprecedented scale and significance by presenting a long history of NGOs' influence. According to Davies, NGOs have had a substantial impact on major developments in world politics in the last two centuries. The development of transnational civil society was cyclical, with peaks in activity in the first decade of the twentieth century, in the early 1930s, and in the late 1990s. In each of these periods, NGOs formed coalitions around major issues, which in all three cases were followed by periods of contraction and fragmentation. ${ }^{38}$

O'Sullivan, Hilton and Fiori identified five key phases of NGO expansion: 1. The intersection of imperial humanitarianism and internationalism in the late nineteenth century; 2. The post-First World War period; 3. The 1940s; 4. The 'NGO moment' (1968-1985) when the rise of global media and crises in the decolonised world led to the creation of a global development industry; and 5. The post-Cold War period. ${ }^{39}$ Our chronology, presented below, is in line with that of previous authors. We, however, do not merely focus on moments of expansion but provide a more general narrative that includes moments of expansion and stagnation, and influence and impotence for NGOs. We also distinguish five periods: 1 . The first rights revolution: 186os to mid-1920s; 2. Exclusion (and thus an insignificant role for NGOs): mid-1920s to mid-1940s; 3. Inclusion: late 1940s to 1950s; 4. Expansion: 196os to 1980s; and 5. Europeanisation in Post-Cold War Europe: 199os to present. What distinguishes our periodisation from that of others is that we interweave the history of humanitarianism with the history of migration governance. While the former has received some attention, the latter is still very much under development since most scholars working on migration governance focus on contemporary issues rather than on what happened in the past.

The role of NGOs depended on the requirements, structure and activities of states and, after 1945, IGOs. When states lacked expert and logistical authority, they called on NGOs for support. The consequence of including NGOs, however, was that NGOs attempted to introduce a form of moral authority that challenged states' moral authority. This meant that when states had little or no

\footnotetext{
37 M.P. Bradley, The world reimagined (New York 2016) 125.

38 Davies, NGOs.

39 O'Sullivan, Hilton and Fiori, 'Humanitarianisms in context', 7.
} 
need for NGOs, they often side-lined them - by reducing financial assistance and excluding or delegitimising them at official fora. IGOs also used similar methods at times as their power increased. IGOs and NGOs were dependent on each other, but also competed with each other. The blurring of lines between NGO and IGO work, representation and organisation, resulted in some NGOS being absorbed into the government system. Gatrell, in this issue, tackles the reliance of NGOS on states and IGOs in considerable depth.

As the nineteenth century advanced, more and more voluntary organisations formed. Drawing on ideals developed during the Enlightenment and the Christian Reform Movement, these organisations began to fight against slavery, trafficking, prostitution, child labour, and alcoholism, to garner charity for the poor and to seek social rights for workers. ${ }^{40}$ In 1863 , Henri Dunant founded one of the most famous NGOs of all, the Red Cross, which derived moral authority from its neutrality claim. In 1873, lawyers set up an international body, the Insitut de Droit International (IDI), which tried to mediate in issues where a lack of harmonisation in laws at the European level led to problems. It was the first attempt to harmonise European policies on migration-related issues. ${ }^{41}$ Migration governance in the nineteenth century was very much the playing field of lawyers and organisations derived their influence from demonstrating expert authority. ${ }^{42}$

Trafficking was one of the most vibrant fields of migration governance in this first period. In the nineteenth century, Britain, the Netherlands, Germany, Belgium and France were at the forefront of drafting international treaties against trafficking in women. Numerous conferences were held and campaigners travelled extensively between countries. The number of newspaper articles that were published on the subject is extraordinary. ${ }^{43}$ It was an issue that enabled NGOs to gain high visibility and make strong moral claims. NGOS

$40 \quad$ Barnett and Weiss, Humanitarianism in question, 18.

41 P. Rygiel, 'Does international law matter? The Institut de Droit International and the regulation of migrations before the First World War', Journal of Migration History 1:1 (2015) 7-31.

42 M. Schrover, 'Dutch migration research: looking back and moving forward', TSEG 11: 2 (2014) 199-218.

43 M. Schrover, 'History of slavery, human smuggling and trafficking 1860-2010', in: G. Bruinsma (ed), Histories of transnational crime (Amsterdam 2015) 41-70. 
reproduced the arguments and strategies from the slavery abolition movement and made use of the new medium of motion pictures. Between 1902 and 1919, several conventions were concluded, which in practice were however ineffective. ${ }^{44}$ The conferences, nevertheless, were venues where NGO representatives met, and where strategies were developed and dispersed.

At the end of the nineteenth century, national (frequently church-based) NGOs actively encouraged emigration from Europe. ${ }^{45}$ In 1906, the International Congress on Unemployment was held. Labour bureaus, international trade unions and NGOs drafted a proposal for international labour exchanges, in the hope of increasing labour emigration, but no country signed it. ${ }^{46}$ The ILO (International Labour Organization, est. 1919) took the lead in organising labour migration after the First World War, but also to little effect. Shipping companies were more effective in their campaigns against restriction and they used American NGOs promoting migrants' rights to their advantage. ${ }^{47}$ The shipping companies did what neither NGOs nor state authorities could do. The role of these shipping companies in the interwar period is discussed by Feys in this issue. His article highlights the role of business in migration governance. Feys discusses how NGOs competed at times with shipping companies but also complemented them at other junctures depending on the circumstances. Both used logistical and expert knowledge, in order to gain authority in their attempts to change refugee policies.

The famine in Russia led to the creation of Save the Children (est. 1919), which later became an active claim maker in migration issues. ${ }^{48}$ It raised over a million pounds within a year for child refugees, branched out to other countries and gained support from Pope Benedict XV and the Red Cross. In 1921, the League of Nations (LoN) called Save the Children its pioneer. Like the

44 M. Lehti and K. Aromaa, 'Trafficking for sexual exploitation', Crime \& Justice 34 (2006) 133-227; J.R. Pliley, 'Claims to protection: the rise and fall of feminist abolitionism in the league of nations' committee on the traffic in women and children, 1919-1936', Journal of Women's History 22:4 (2010) 90-113.

45 M. Schrover and M. van Faassen, 'Invisibility and selectivity. Introduction to the special issue on Dutch overseas migration in the nineteenth and twentieth century', TSEG 7:2 (2010) 3-31.

46 S. Charnovitz, Two centuries of participation: NHOs and international governance', Michigan Journal of International Law 18:183 (1996-1997) 184-286.

47 Charnovitz, Two centuries of participation', 184-286.

48 T. Sasson 'From Empire to humanity: The Russian famine and the imperial origins of international humanitarianism,'Journal of British Studies 55 (July 2016) 519-537. 
Red Cross before it, Save the Children gained moral authority because of its references to innocent victims and neutrality. ${ }^{49}$

During the First World War, 20 million people became refugees and internally displaced persons in Europe. This led to the demise of 'adhocracy' amongst NGOs and the move towards a more organised response to crisis. ${ }^{50}$ Government budgetary constraints and the number of refugees allowed NGOS to raise their profile..$^{51}$ According to Cabanes a 'transnationalisation of humanitarianism' took place because of globalisation and the inability of states to cope with the enormous humanitarian fallout from the First World War. ${ }^{52}$ This unification of resources became particularly evident in NGOs' response to the crisis caused by the migration of Russian refugees in the 1920 .

During and after the First World War, 1 million Russians fled ${ }^{53}$ and most were deprived of their citizenship by Soviet authorities. Following a meeting of NGOs concerned with Russian refugees in 1921, the Red Cross demanded, on behalf of all NGOs, more support from the recently established LoN. Gustave Ador, the President of the Red Cross, suggested the 'appointment of a LoN Commissioner for the Russian refugees'. According to Ador this was 'not so much a humanitarian duty which calls for the generous activities of the League of Nations as an obligation of international justice. ${ }^{44}$ The LoN named Fridtjof Nansen as the first High Commissioner for Russian Refugees in 1921. Nansen was a highly popular sportsman, explorer and war hero. When governments unanimously approved Nansen's September 1921 resolution to 'obtain the collaboration of private relief organisations which hitherto have contributed to the relief work in connection with Russian refugees' and 'to associate them directly with his work', it symbolised the vital role NGOs played in the early 1920 s. ${ }^{55}$ Nansen's office received funds raised by NGOS (the office's budget was tiny) and NGOs could ask the LoN to help them circumvent national bureaucratic difficulties. An Advisory Committee of Private Organisations

49 A. Nehlin, Exporting visions and saving children - the Swedish Save the children Fund, Linköping Studies in Arts and Science No. 494 (Linköping 2009).

5o J. Lissner, The politics of altruism (Geneva 1977).

$51 \quad$ P. Gatrell, The making of the modern refugee (Oxford 2013) 20.

52 B. Cabanes, The Great War and the origins of humanitarianism, 1918-1924 (Cambridge 2014).

53 J.H. Simpson, The refugee problem. Report of a survey (London 1939) 62.

54 Letter from Gustave Ador to the League of Nations, 20 Feb 1921. Published in the League of Nations, Official Journal, 'The Question of Russian Refugees', Annex 2, 228, 1921.

55 League of Nations Conference on Russian Refugees, 17 Sept 1921, C.R.R./2 ${ }^{\text {nd }} \operatorname{session} /$ P.V.2. 1921, League of Nations archives. 
met regularly with the High Commissioner. Responding to the lobby by NGOS (including the IDI), Nansen introduced what became known as the Nansen Passport: it gave stateless Russians identity papers which enabled them to travel to find relatives or work for a twelve-month period. The Nansen Passport relieved places such as Constantinople, where many refugees were marooned and living in dire conditions.

At more or less the same time, hundreds of thousands of children from Austria-Hungary, Russia and Germany were transferred to Britain, Switzerland, the Netherlands, Belgium and the Nordic countries under the supervision of the Red Cross, Caritas (est. 1863) and Save the Children. It was meant to be a temporary migration, but it led to permanent adoption in about half the cases. NGOs started to push for the harmonisation of laws on adoption. ${ }^{56} \mathrm{~A}$ steadfast belief in the ability to manage migration - which characterised this period also led to the 1923 Population Exchange between Turkey and Greece. It was designed and supervised by Nansen and commissioned by the LoN. For the Population Exchange, which affected more than two million people, Nansen recruited the help of NGOs such as the Red Cross and Near East Relief (NER est. 1915). ${ }^{57}$ According to Rodogno and Piana, the Red Cross and other NGOs focused on 'scientific administration of relief' which was in reality biased, selective and semi-colonial. 58

Overall, in this long first period NGos proved markedly influential. They cooperated in presenting their ideas to policy makers and IGOs; a strategy which worked well. NGOs caught and held the attention of the public with highly innovative campaigns. The Red Cross, the anti-trafficking organisations, and Save the Children possessed strong moral and expert authority. IGOs, such as ILO and IDI, mostly had expert authority. Organisations such as the NER and Red Cross had logistical authority, although the shipping companies outdid them when it came to migration governance because of their resources and experience. States required national and transnational assistance from non-state actors to help countries recover after the war. The large number of refugees was presented as proof of the failure of new states - Turkey and the Soviet

$5^{6}$ V. Hajtó, "The "wanted" children: Experiences of Hungarian children living with Belgian foster families during the Interwar period', The History of the Family 14:2 (2009) 203-216; V. Hajtó, Milk sauce and paprika: Migration, childhood and memories of the interwar Belgian-Hungarian Child Relief Project (Leuven 2013).

57 J.F. L.Ross, 'Fridtjof Nansen and the Aegean population exchange', Scandinavian Journal of History 40:2 (2015) 133-158.

58 D. Rodogno, S. Gauthier, and F. Piana, 'The League of Nations mission in Western Thrace: Relief and rehabilitation operations (1922-1924)', in: J. Paulmann (ed), Dilemmas of humanitarian aid in the twentieth century (London 2016) 147-170. 
Union - in the eyes of their opponents. Political changes and the balance of power were instrumental to the effectiveness of NGOs.

By the mid-1920s, most European states had recovered from the war and looked to the future. States reasserted their dominance and had less need for NGOS. During the 1930s, economic depression and growing nationalism meant that defending migrants' rights became more difficult. It affected NGOs' room to manoeuvre. Problems in Poland, Fascism in Italy, Nazism in Germany, and the Civil War in Spain drove out large numbers of people. Devastating unemployment and growing tension meant these people generally faced a hostile reception despite the efforts of NGOs to stand up for migrants and refugees.

In 1925, the High Commissioner for Refugees transferred the task of finding work for refugees to the ILO. In 1924, the Comité International des Organisations Privées pour la Protection des Migrants (CIOPPM) was created, encouraged by the Jewish Colonization Association and supported by the ILO. In the first few months of 1924, 60 NGOs joined the CIOPPM. Its headquarters were in Geneva to allow close cooperation with the ILO. The CIOPPM campaigned for transport costs to be fixed before departure, reduction of waiting times at stations, and help for migrants with visa applications. In 1928, the Second International Emigration and Immigration Conference was held in Havana, with experts from 64 countries. With three of the most important immigrant receiving countries absent - Canada, Brazil and the US - and disagreement about goals among the participants, this conference had little effect. ${ }^{59}$

NGOs pushed for a draft convention on the rights of Russian and Armenian refugees from the late 1920 on onwards. ${ }^{60}$ NGOs pressed the Intergovernmental Committee on Refugees for the LoN to summon states together in 1933. The 1933 Convention Relating to the International Status of Refugees contained a number of significant recommendations relating to labour conditions,

59 P-A. Rosental, 'Géopolitique et État-providence. Le BIT et la politique mondiale des migrations dans l'entre-deux-guerres', Annales. Histoire, Sciences Sociales 61:1 (2006) 99-134.

6o J.C. Hathaway, The rights of refugees under international law (Cambridge 2005) 86; G. Gousseff, L'Exil Russe. La Fabrique du Réfugié Apatricide (Paris 2008) 236 ; Y. Schacher, 'Refugees and restrictionism: Armenian women immigrants to the USA in the post-World War I era', in: M. Schrover and D. Moloney (eds), Gender, migration and categorisation: Making distinctions between migrants in Western countries (1900) 1945-2010 (Amsterdam 2013) $55^{-74}$. 
industrial accidents, and welfare and education. Yet only eight countries ratified the convention - and only then with varying reservations. ${ }^{61}$ In 1933 , the LoN appointed an autonomous High Commissioner responsible for German refugees, the American James MacDonald. The new office had to appropriate funds privately to appease Germany's objections to the LoN. ${ }^{62}$ McDonald resigned from his post after two years, and blamed the growing crisis facing Jewish and non-Jewish refugees on the intransigence of the international community. The LoN sought to reform itself and tried to involve civil society to a greater extent. The attempt failed but the ideas that were floated were used by the UN in the post-war period. ${ }^{63}$

In July 1938, 29 governments met in Evian to discuss the situation of refugees escaping from Nazism. The US did not send a delegate to Evian, did not increase quotas, and accepted only very few Jewish refugees. Other countries similarly took few or no refugees. The number of German Jewish refugees, whose fate was discussed at Evian, was 225,000 - much fewer than the number of Russian refugees twenty years earlier. Thirty-nine NGOS, including 21 Jewish organisations, attended the conference. They did so in an unofficial capacity, even though the conference maintained that refugee welfare would remain the responsibility of voluntary organisations rather than states. The Evian conference's negligible recommendations - the creation of the Intergovernmental Refugee Committee, which lingered in obscurity from October 1939 until 1943demonstrated the ineffectiveness of NGOs. ${ }^{64}$

The economic depression of the 1930s resulted in xenophobic attitudes and restrictive migration regimes. The absence of cooperation with the LoN and the lack of agreement between NGOs - in line with the ideological fragmentation between European states - contributed to the futility of NGOS and IGOs' efforts. Neutrality claims no longer provided moral authority, and saving 'ourselves' proved to be more important than saving the innocent. An interesting case study in this context is presented by Caestecker in this issue. He studies the reception of German communists in European countries, focussing on the

61 R. Beck, 'Britain and the 1933 Refugee Convention: National or state sovereignty?', International Journal of Refugee Law 11:4 (1999) 597-624, 622.

62 L. Holborn, Refugees: A problem of our time Vol. I (Metuen, N.J., 1975) 14.

63 I. Glynn, 'The genesis and development of article 1 of the 1951 Refugee Convention', Journal of Refugee Studies 25:1 (2012) 134-148.

64 I. Glynn, 'More power, less sympathy: The response of IGos in Western Europe to unwanted migration during economic crises compared', Comparative Population Studies Zeitschrift für Bevölkerungswissenschaft 37:1-2 (2012) 99-120, 104; T. Sjöberg, The powers and the persecuted. The refugee problem and the Intergovernmental Committee on Refugees (IGCR), 1938-1947 (Lund 1991). 

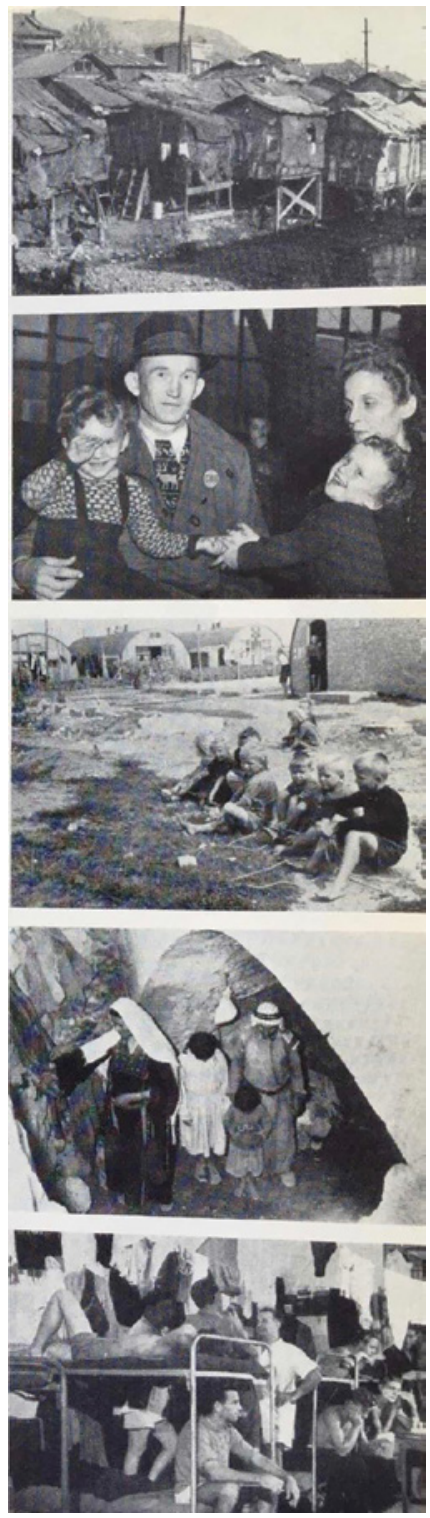
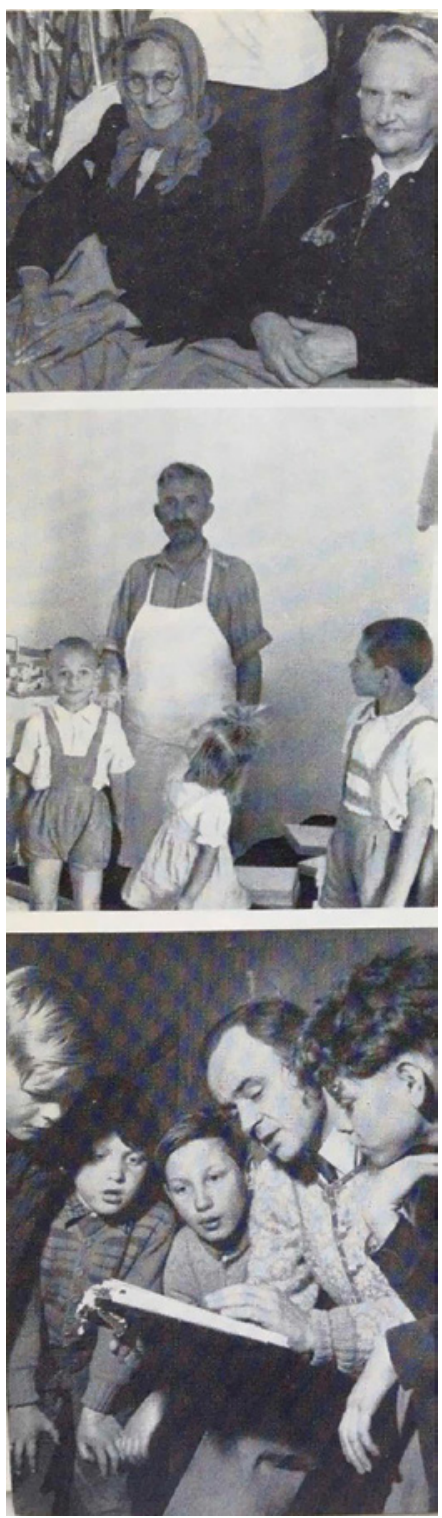

ILLUSTRATIONS 1 AND 2 Propaganda material from the World Council of Churches from the 1950s emphasises the fact that refugee migration is a world problem. Left top to bottom: Korean refugee shacks, Pusan; Church World Service sponsored refugees ready to sail for new homes in America; Children of unemployed refugees in a nissen camp, Kiel; Cave homes of Arab refugees in Jordan; Young refugees awaiting migration opportunities in Trieste camp. Right top to bottom: Refugees from China rest in their plane at Geneva, en route to church homes in Belgium; Resettled refugee by the wcC in Tripolis, Greece, this Rumanian refugee is now a successful candy maker; In a Berlin refugee centre a church counsellor teaches refugee youth. SOURCE: ARCHIVE WORLD COUNCIL OF CHURCHES, GENEVA. 
role of the Red Help, a refugee aid organisation. Caestecker demonstrates that NGOs were at times able to counter some of the prevailing economic and political arguments used by states but not interminably because they possessed limited logistical or expert authority. The Red Help was most effective in lobbying for asylum of communist refugees when it became more accommodating to the authorities.

Inclusion: Late 1940s-1950s

After the Second World War, states vowed to make sure that the newly formed United Nations would serve the world better than its predecessor, the LoN. The Charter of the United Nations, signed in 1945, insured, cemented and enhanced the role of NGOs.

In post-war Western Europe, the housing shortage was the most pressing problem. It led to restrictive immigration regimes, and to the facilitation of large-scale emigration from Europe to Australia, Canada and the US. At the same time, hundreds of thousands of people 'returned' from the colonies to Europe. In the immediate post-war period there were 14 million Displaced Persons (DPs) in Europe, plus 12 million expellees (ethnic Germans from countries that had been under Nazi rule and who were expelled to Germany after the war). ${ }^{65}$ The expellees were explicitly defined as non-DPs and non-refugees by the parties discussing an international solution to the DP or refugee problem. NGOs (such as Caritas), however, came out in support of the expellees, countering the revenge frame favoured by other claim makers, and thus gained moral authority. ${ }^{66}$ Although NGOs did try to find a common solution to the refugee problem, the very same NGOs clashed on other issues, for instance on what to do with Jewish orphans who had survived the war. Christian NGOs advocated for the rights of Christian foster parents, and Jewish NGOs wanted the children to grow up in Jewish families or in Jewish orphanages. ${ }^{67}$ These debates increased visibility for NGOS.

65 G. D. Cohen' 'The "Human Rights Revolution" at work: Displaced Persons in postwar Europe', in: Hoffmann (ed), Human rights in the twentieth century, 45-61; M. Schrover and T. Walaardt, 'Displaced persons, returnees and "unsuitables": the Dutch selection of DPs (1945-1951)', Continuity and Change 33 (2018) 413-440.

66 M. Schrover, 'The deportation of Germans from the Netherlands 1946-1952', Immigrants \& Minorities 33:3 (2015) 250-278.

67 J.S. Fishman, 'The Anneke Beekman affair and the Dutch news media', Jewish Social Studies 40:1 (Winter1978) 3-24. 
During the war, the ILO created a Permanent Migration Committee, which studied the need for an international body that would organise the selection of (labour) migrants. The ILO however failed to take a leading role because a strict separation was made (and advocated for) between refugees and other migrants. ${ }^{68}$ The ILO, which had been active but largely ineffective in the interwar period, became increasingly dysfunctional in this period because it served too many (conflicting) goals in too many countries (increasingly also working in the recently decolonised countries). ${ }^{69}$

The I Ro (International Refugee Organization 1947-1950) took over the ILO's role after the war, precisely because it managed to blur the lines between categories of migrants. It was said to function as the largest employment and travel agency in the world, which 'sold' DPs and refugees as workers. By re-labelling and allocating them with the category 'labour migrants', the IRO improved refugees' chances of migration. The IRO appealed directly to authorities and campaigned via the press. The IRO was able to enforce European cooperation because it had money and shipping capacity. The relationship between the former allies deteriorated rapidly on the eve of the Cold War. As a result, between 1945 and 1951 several IGOs aiming at regulating international migration were established in rapid succession. The creation of a large number of organisations indicated both support for finding mutual solutions, as well as extreme fragmentation, competition and disagreement between NGOs and IGOS, and between states. IGO activity stimulated rather than pushed out NGO activity. New NGOS and NGO coordinating groups were created in response, such as the wCC (World Council of Churches est. 1948) and ICMC (International Catholic Migration Commission est. 1951). ICEM (Intergovernmental Committee for European Migration 1952-1980) was able to regulate migration with the benefits of multilateral cooperation. It inherited the organisational infrastructure and the shipping fleet of the IRo. ${ }^{70}$

Parsanoglou and Papadopoules, in this issue, describe the workings of the ICEM in the first 10 years after its establishment in $195^{2}$ as 'part of the US propaganda mechanism during the Cold War.' They elaborate on the cooperation

68 R. Karatani, 'How history separated refugee and migrant regimes: In search of their institutional origins', International Journal Refugee Law 7:3 (2005) 517-541.

69 L.R. Helfer, 'Understanding change in international organizations: Globalization and innovation in the ILO', Vanderbilt Law Review 5 9:3 (2006) 651-722.

70 F. Georgi, 'For the benefit of some: The International Organization for Migration and its global migration management', in: M. Geiger and A. Pécoud (eds), The politics of international migration management (Basingstoke 2010) 45-72. 
of the ICEM with other international organisations, states and NGOS. It showed how multiple tasks and activities were outsourced to NGOs. They show how NGOS created the possibility to disseminate information to migrants (expert authority), to process and document migrants (logistical authority) and to promote additional resettlement (moral authority). We thus see that these concepts of authority moved in reciprocal directions. NGOs did not only use these concepts to influence others, but they were also used by ICEM to establish their expert, logistical and expert authority.

Awareness that the failure of Evian had sealed the fate of Germans Jews, growing tensions relating to the Cold War, and the rejuvenation of inter-war ideas about refugee rights led to the establishment of the 1951 Refugee Convention. Most of the work behind the draft convention came from IRO staff members, who had personal experience of asylum and who were previously involved in pro-refugee NGOS. Twenty-five governments and the head of the newly formed UNHCR (United Nations High Commissioner for Refugees, est. 1950) attended the conference of plenipotentiaries that took place in July 1951 to sign the Refugee Convention. Twenty-one NGOs were given observer status but their impact on the convention was officially muted. ${ }^{71}$ Yet, as Ben-Nun showed, Jewish NGOs helped to develop significant sections of the convention through their personal contacts and networks rather than through more formal, visible routes. ${ }^{72}$ The UNHCR began life as a financially and politically weak organisation, mainly because the US refused to contribute to an organisation that functioned outside of its control. The UNHCR, in collaboration with the wCC, War Relief Services, the American Jewish Joint Distribution Committee and the Lutheran World Federation, appealed to the Ford Foundation, which in response gave $\$ 3.1$ million. ${ }^{73}$ The effectiveness of UNHCR's work with refugees from East Germany in 1953 and the political expediency that states gained from welcoming communist defectors meant substantial state funding to UNHCR followed. ${ }^{74} \mathrm{NGO}$ efforts and the political situation led to the expansion of UNHCR in this period.

\footnotetext{
$71 \quad$ Glynn, 'The genesis and development of Article 1'.

72 G. Ben-Nun, 'The Israeli roots of Article 3 and Article 6 of the 1951 Refugee Convention', Journal of Refugee Studies 27: 1 (2014) 101-125.

73 Draft of minutes of meeting with Ford Foundation, 25 March 1952, 4.o GEN, Voluntary Agencies. General 4, Series 4.0 GEN Fonds 11 UNHCR Archives.

74 UNHCR, Final report on the Ford Foundation program for refugees, primarily in Europe, implemented by voluntary agencies and administered through the United Nations High Commissioner for Refugees (Geneva 1958).
} 
Since people were largely unable to cross the Iron Curtain, the numbers of refugees dwindled until the 1956 Hungarian Uprising. The number of people fleeing Hungary in 1956 was not large $(225,000)$ and public support for these refugees, who were perceived to prove capitalism right and communism wrong, was enormous. Large media campaigns created a willingness to donate money to NGOs. The 1956 Hungarian refugee crisis saw UNHCR named as the lead agency to coordinate assistance. The US took a large number of the Hungarian refugees. ${ }^{75}$ Economic growth and an increasing demand for labour in Western Europe also made accepting refugee migrants an acceptable option. ${ }^{76}$

Overall, this was a period of expansion and inclusion, in which the number of IGOs and NGOS and their cooperation and interdependence grew. The logistical and expert authority of NGOs benefited IGOs such as UNHCR. On the one hand, the growth of the number of IGOs helped NGOs because they could act as (usually) sympathetic agents with direct access to states. On the other hand, this development meant that NGOs were no longer the only or main aid providers and IGOs could be competitors. The growth of UNHCR, for example, resulted in a decrease of logistical authority for NGOS, as IGOs slowly became powerful actors in their own rights, in marked contrast to the inter-war period.

Until the early 1970s, West-European economies grew, and guestworker migrants were attracted to remedy labour market shortages. Some migrants could have asked for refugee status, but migration within the guestworker migration regime was simpler. After 1975, the possibilities for labour migration declined, and family migration and refugee migration consequently increased. In the 1960 and 1970s, attention for refugees outside Europe became more important. European NGOs gained high visibility with their campaigns for Chinese refugees, who fled to Hong Kong at a rate of 2,00o per day in 1962, for refugees from Biafra (Nigeria) in 1969, and for the millions of refugees from Eastern Pakistan (Bangladesh) in 1971. The number of international NGOs and IGOs involved in

75 A.A. Markowitz, 'Humanitarianism versus restrictionism: The United States and the Hungarian refugees', International Migration Review 7:1 (1973) 46-59; Loescher, The UNHCR and world politics; J. Granville, 'Between Scylla and Charybdis: Austria's first test case of neutrality during the Hungarian Crisis, 1956-57', Journal of Communist Studies and Transition Politics 26:4 (2010) 494-517.

76 M. Schrover and T. Walaardt, 'The influence of the media on politics and practices: Hungarian refugee resettlement in the Netherlands in 1956', Journal of Migration History 3 (2017) 22-53. 


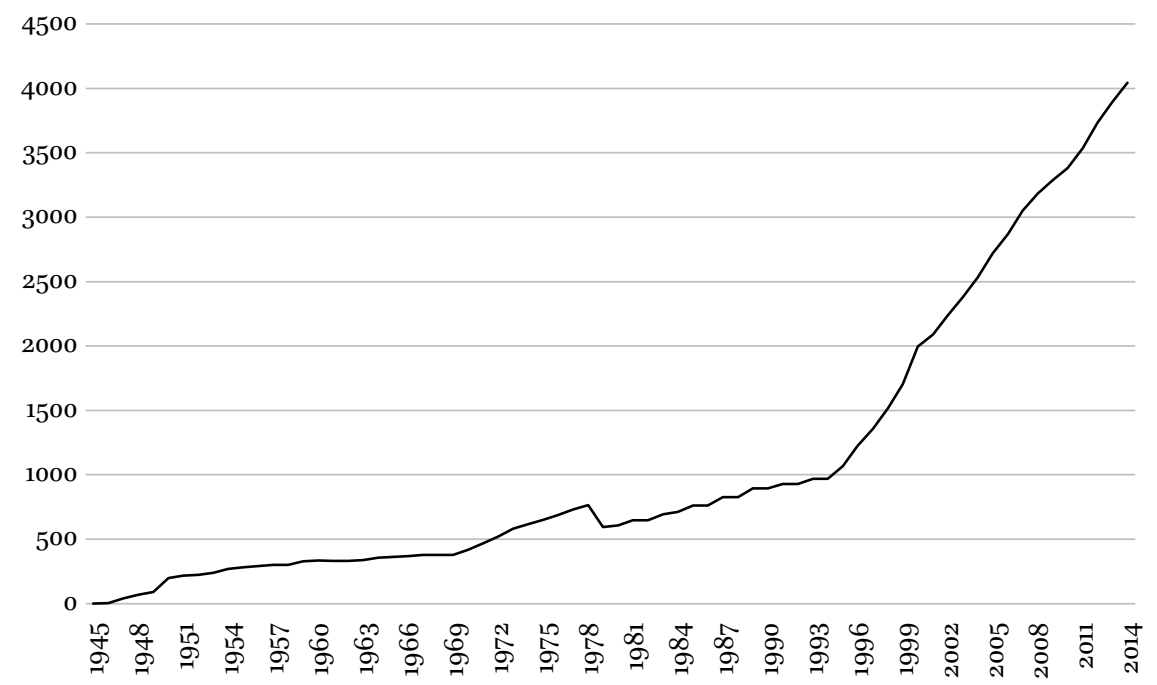

FIGURE 1 Numbers of NGOs in Consultative Status with the United Nations Economic and Social Council for each Year 1945-2014.

SOURCE: DATA COLLECTED BY PETER WILLETTS HTTP://WWW.STAFF.CITY.AC. UK/P.WILLETTS/NGOS/NGO-GRPH.HTM

migration issues began to expand, particularly in Europe. The number of NGOs in Consultative Status with the United Nations Economic and Social Council almost doubled between 1959 and 1981 (see Figure 1).

The British lawyer Peter Benenson founded Amnesty International in 1961. Ten years later, a group of French doctors founded Médecins Sans Frontières (MSF) after experiencing at first-hand the suffering in Biafra. The Biafran humanitarian crisis made older NGOs, such as Oxfam (est. 1942), Save the Children, and Caritas more visible. The wars in Vietnam and Biafra, and the Portuguese colonial wars in Angola, Mozambique and Portuguese Guinea (1961-1974) were the first major televised wars. A large audience was exposed to horrifying images on a daily basis: starving children, endless numbers of victims, and soldiers who were no longer heroes. Conflicts led to large-scale internal and international displacements, and increases in the number of refugees. European NGOs reacted by acting more globally. Teams of European workers and newly hired local staff combined in attempts to alleviate suffering. It is debatable how effective European NGOs were. Indeed the growing involvement of European NGOs in recently decolonised states led some scholars to suggest that the globalisation of NGOS represented a new form of colonialism. ${ }^{77}$

Student protests across Western Europe in 1968, the peace marches against American involvement in Vietnam, America's foreign policy in South America, 
the assassination of Chile's leader Salvador Allende (1973), and the Watergate scandal (1974) created resistance towards the traditional political system. NGOs in Europe appealed for support for Chilean and Vietnamese refugees. This helped to lead to the Geneva Conference on 20-21 July 1979 on Vietnamese boatpeople, which sought a solution at an international level. NGOS, in response to anti-political sentiment, explicitly moved attention in their campaigns away from political causes. Instead, they increasingly became mediators. ${ }^{78}$ Part of the NGOs also started to work together more. From the 1980 s onwards, NGOs formed conglomerates in their bids for money, and as a way of consolidating their influence and power. The end of the Cold War opened up new political space for NGOS, which was further increased by changes in communications. Networking between organisations ensured increased power. By the 1980s, NGOs had firmly established themselves as the essence of civil society in the West. ${ }^{79}$

The economic recession of the 1980 s led to restrictive immigration regimes and the illegalisation of migration into Western Europe. State authorities left it to NGOs to solve the problems of migrants without legal residence status. Development NGOs started to advocate strongly in favour of helping the countries of origin of migrants in order to reduce migration. It was a policy that was supported by IGOs such as the IOM (International Organization for Migration est. 1989) and ILO. ${ }^{80}$ European NGOS became prominent actors throughout the world during this period.

\section{7 \\ Europeanisation in Post-Cold War Europe: 199os to Present}

The UN had granted consultative status to 41 NGOs in 1946. By 1992 more than 700 NGOs had attained consultative status and the number has increased to over 5,000 today. ${ }^{81}$ This rise mirrored developments in the politics of asylum, as NGOS advocating for the rights of refugees and asylum seekers grew

78 P. Willetts, 'Non-Governmental Organizations', in: Unesco Encyclopedia of Life Support Systems, Section 1; Institutional and infrastructure resource issues (Paris 2001).

79 M. Kjaerum, 'Human rights organisations and the formation of refugees regimes', in: D. Joly (ed), Global changes in asylum regimes (Gordonsville 2003) 204-214.

$80 \quad$ P. Stalker, 'Migration trends and migration policy in Europe', International Migration 40:5 (2002) 151-179; H. de Haas, "Turning the tide? Why "development instead of migration" policies are bound to fail', Working papers International Migration Institute paper 2 (Oxford 2006).

81 UN Department of Economic and Social Affairs. Accessed at http://csonet.org/ (16 November 2018). 
enormously: the UNHCR listed 39 NGOs working for refugees in 1950, while the OECD reported 1,300 such NGOS by the early 1990s. ${ }^{82}$

The end of the Cold War resulted in more opportunities and tasks for IGOs. Iом became very active in Central and Eastern Europe, and a much stronger party in migration governance than its predecessors had ever been. It sought to manage migration by educating government officials and others in the countries of origin or transit of migrants. This form of education was combined with economic, political, financial, and military inducements. ${ }^{83}$ In the 1990s, the ILO also sought stronger cooperation with NGOs.

The outbreak of the civil war in Yugoslavia in 1991 led to new refugee migration in Europe. By August 1992, approximately 2.5 million people had fled their homes as fighting in the Balkans spread. Almost 2 million were displaced within former Yugoslavia and 633,938 sought asylum in Western European countries by 1994, the majority were Muslims from Bosnia. ${ }^{84}$ NGOs were able to mobilise support from organisations, which had originally catered to the needs of the Yugoslav guestworkers (of which there were about 600,000 in Germany).

EU Member States' attempts to restrict immigration, from the economic recession of the 1980 s onwards, required a certain sophistication because of their duty to respect the European Convention on Human Rights, enforced by the European Court of Human Rights (ECtHR) and, to a lesser extent, the European Court of Justice. In 1983, amended rules for the ECtHR allowed individuals to take cases before the court. The bestowal of rights on 'persons' rather than 'citizens' allowed it to hear cases concerning Europeans and non-Europeans alike. ${ }^{85}$ The European Convention's legal superiority over domestic legislation has meant that it serves as a bill of rights for certain countries without liberal constitutions. 'Going to Strasbourg' became a strategy NGOs deployed

82 UNHCR, Memo from Alexander to Goedhard, 29 Dec 1950, Voluntary Agencies, Series 4, Fonds 4 4.oGen, Records of the Central Registry, Archives of the UNHCR; OECD, Human rights, Refugees, Migrants and Development: Directory of NGOS in OECD countries (Paris 1993).

83 R. Andrijasevic and W. Walters, 'The International Organization for Migration and the international government of borders', Environment and Planning D: Society and Space 28 (2010) 977-999.

84 Silva Meznaric and Jelena Zlatkovic Winter, 'Forced Migration and Refugee Flows in Croatia, Slovenia and Bosnia-Herzegovina', Refuge 12.7, 1993, 3-5; U N HCR, Asylum Applications in Industrialized Countries: 1980-1999, UNHCR: Geneva, 2001, 82.

85 D. Jacobson, Rights across Borders: Immigration and the Decline of Citizenship (Baltimore 1996) 83 . 
increasingly in the 1990 and especially the $2000{ }^{86}{ }^{86}$ The ECtHR's case law became 'the backbone of EU law on asylum' and the court has played 'a decisive role in protecting the fundamental rights of aliens facing expulsion:. ${ }^{87}$ Significantly, the ECtHR repeatedly calls international human rights NGOS, such as Amnesty and Human Rights Watch, as well as the UNHCR, as expert witnesses. ${ }^{88}$ These types of human rights monitoring bodies are becoming more powerful because they have 'developed a sound body of case-law on the rights of non-nationals in relation to the entry and stay, as well as non-removal from their countries of asylum' which has increased their expert and moral authority extensively. ${ }^{89}$

Following the completion of the Amsterdam Treaty in 1997, the European Council meeting at Tampere in 1999 signalled the beginning of the increasing Europeanisation of asylum and migration. ${ }^{90}$ This led to the establishment of European bases for many international NGOs so that they could influence and engage with decision makers in Brussels. The development of the European Asylum Support Office soon afterwards presented NGOs with several difficulties because it was not always clear who they needed to lobby as national delegates, Eurocrats, embassy staff and national civil servants all contributed to the development of various European directives associated with asylum, as demonstrated by Strik in this issue. Strik shows that although NGOs possessed expert and logistical authority, they found it extremely difficult to influence important policy decisions in the early 2000 s because of the labyrinthine nature of EU policymaking.

The civil war in Syria, which began in 2011, led to the displacement by 2018 of 6.6 million people within Syria, while 5.6 million were registered as refugees by UNHCR in neighbouring countries. Over 3.6 million Syrian refugees reside

86 S. van Walsum, The family and the nation: Dutch family migration policies in the context of changing family norms (Newcastle 2008); M. Schrover, 'Family in Dutch migration policy 1945-2005', The History of the Family 14 (2009) 191-202; M.A. Schain, 'The state strikes back: Immigration policy in the European Union', The European Journal of International Law 20:1 (2009) 93-109.

87 H. Labayle and P. De Bruycker, 'The influence of ECJ and ECtHR case law on asylum and immigration', Report requested by the European Parliament's Committee on Civil Liberties, Justice and Home Affairs (LIBE) (Brussels 2012) 5 and 11.

88 See, for example, Hirsi Jamaa and Others v. Italy (2012) 27765/o9, Judgment of 23 Feb. 2012.

89 M.T. Gil-Bazo, 'Introduction: The role of international organizations and human rights monitoring bodies in refugee protection', Refugee Survey Quarterly 34:1 (2015) 1-10.

9o E. Haddad, 'The external dimension of EU refugee policy: A new approach to asylum?', Government and Opposition 43:2 (2008) 190-205. 
in Turkey, approximately 1 million in Lebanon, and over 650,00o in Jordan. ${ }^{91}$ Between 2011 and 2017, over one million Syrians applied for asylum in the EU. ${ }^{92}$ IGOS (e.g. UN HCR, IOM) and NGOS (e.g. Caritas, MSF) are instrumental in the support and accommodation of asylum seekers and refugees in countries neighbouring Syria. All NGOs have developed extensive support campaigns, largely following strategies that were used in earlier campaigns. IGOs and NGOS became more critical of EU and Member State policies when the Member States became more dependent on their support. MSF for example refused EU funding to protest against EU deterrence policies. ${ }^{93}$ Yet, when state control returned, as occurred after the introduction of the EU-Turkey deal, states began to demote NGOs and IGOs.

In recent decades, new EU Member States have become the special concern of NGOs fighting trafficking. ${ }^{94}$ The Czech Republic, for instance, is named as a transit and destination country for women trafficked from Ukraine, Russia, Belarus, Moldova, Lithuania, Romania, Bulgaria, Slovakia, China and Vietnam. NGOs offer packages - information which helps these states to bring their policies in line with EU guidelines, and strategies for how to address the media - to new Member States in order to fight trafficking, and by doing so these NGOs exercise influence on how the policies in these countries are shaped.

The ILO and IOM both developed new methods to estimate the extent of human trafficking. ${ }^{95}$ NGOs - such as La Strada (est. 1995), the Coalition Against Trafficking in Women (CATW), and the Global Alliance Against Trafficking in Women (GAATW) - also provided estimates. The statistics they provide are widely used and give the organisations authority. In 2002, a European Conference on Preventing and Combating Trafficking in Human Beings was organised under the framework of the European Commission's sтор programme and

91 UNHCR, 'Syria Regional Refugee Response', last updated on 28 November 2018. Available at https://data2.unhcr.org/en/situations/syria.

92 Eurostat, 'Asylum and first time asylum applicants by citizenship, age and sex Annual aggregated data (rounded)', last updated on 24 October 2018 [migr_asyappctza].

https://www.msf.org.uk/article/msf-no-longer-take-funds-eu-member-states-and -institutions (8 December 2016).

94 R. Andrijasevic, Trafficking in women and the politics of mobility in Europe. $\mathrm{PhD}$ thesis. Utrecht Women's Studies University of Utrecht (Utrecht 2004)'; L. Agustin, 'Migrants in the mistress's house: other voices in the "trafficking" debate', Social Politics: International Studies in Gender, State and Society 12:1 (2005) 96-117; B. Anderson and J. O'Connell Davidson, 'The trouble with trafficking', in: C. van den Anker and J. Doomernik (eds), Trafficking and women's rights (London 2006) 11-26.

95 Andrijasevic and Walters, 'The International Organization for Migration'; A. Pécoud, 'What do we know about the International Organization for Migration?', Journal of Ethnic and Migration Studies 44:10 (2018) 1621-1638. 
took place in the European Parliament with the co-operation of the IOM, the European Commission, the Parliament and EU Member States. The conference brought together more than 1,00o representatives of European institutions, EU Member States, candidate countries, developing countries, IGOs and NGOS. ${ }^{96}$ The IOM and ILO became more important in migration governance because of their involvement in this domain.

In the post-9/11 period, NGOs were increasingly called upon to combine migration and security issues. Both developments strengthened the role of NGOs and recognised their expert authority. Internal politics were important because large and established NGOs joined forces in order to consolidate their influence and IGOs sought the expertise and logistical authority of NGOs. Boundaries between categories of migrants blurred once again. The eastward expansion of the EU, the increasing Europeanisation of asylum and migration issues and the EU membership of new states with weak civil societies resulted in a larger playing field for NGOs. Interestingly, while trade union and political party membership in Europe has declined, the number of NGOs has grown. This suggests that NGOs have partially filled this space. But Sending and Neumann note that this does not signify a simple neoliberal transfer of power from the state to non-state actors but rather that there has been 'a changing logic or rationality of government. ${ }^{97}$ This obviously has serious implications for NGOS, with Hilton warning that NGOs have consequently 'become implicated within wider processes of the professionalisation that lies at the heart of the modern state and which calls into question the claim of being "non-governmental". 98

Based on our overview presented above, we argue that five factors explain the changing role of NGOs: the position of states and their activities; geopolitical power relations and national politics; societal changes; internal politics; competition and cooperation between NGOs and with IGOs.

In the first place, the loss of control by states (e.g. following the arrival of large numbers of refugees) impacts the role of NGOs. This is when states really need NGOS and IGOs to provide the expert and logistical authority that they are lacking. When state policies are challenged, 'windows of opportunity' are

96 J. Goodey, 'Human trafficking: Sketchy data and policy responses', Criminology \& Criminal Justice 8:4 (2008) 421-442.

97 Sending and Neumann, 'Governance to governmentality'.

98 M. Hilton, 'Politics is ordinary: non-governmental organizations and political participation in contemporary Britain', Twentieth Century British History 22:2 (2011) 230-268, 234. 
created for NGOS and IGOs. ${ }^{99}$ States 'reconcile their normative beliefs' to suit their new situations. Norm entrepreneurs, such as NGOs, enter debates on such occasions in an attempt to introduce new norms that favour migrant interests. When states re-attain control, they seek to roll back on the moral concessions they have provided in exchange for NGOs' logistical and expert authority.

Second, changes in geo-political power relations and national politics (e.g. the beginning/end of the Cold War) affect the role of NGOs. The support of NGO goals from major political powers (e.g. the US or the EU) strengthens the role of NGOs. The sparring partners of NGOS are mostly nation states, and these to a large extent create the opportunity structures in which NGOs function. Neoliberalism also supports the view that state interests are best served by delegating tasks to NGOs. In this issue Gatrell pays particular attention to the role that states play in determining the success or failure of NGOS.

Third, societal changes influence the role of NGOs. ${ }^{100}$ Christian organisations were important throughout the long twentieth century, but their position changed over time due to secularisation. Jewish NGOs (briefly) possessed influence in the late 1940 s because of the horrors of the Holocaust. Societal change includes the consequences of technological developments (especially in communication and travel) and the changing possibilities for media campaigns. In order to capture and hold the media's attention, NGOs must be innovative, while they also need to invest in maintaining networks and upholding reliability.

Fourth, NGOs' internal politics and strategies are important. NGOs can conduct highly visible, rapid, personalised and aggressive campaigns, which may have traction but will not give them a place at the negotiating table (outsider tactics). ${ }^{101}$ Or they can choose low-key campaigns which will make them part of the system they seek to ameliorate (insider tactics). A place at the table will lead to professionalisation and bureaucratisation, as well as a loss of spontaneity, which can reduce the influence of NGOs. ${ }^{102}$

Lastly, large and established NGOs have vast knowledge and large networks that branch out into multiple domains and many countries. Authors have labelled the process in which NGOs sponsor some local organisations, while

\footnotetext{
99 Orchard, A right to flee, $6-7$.

100 D. Gnes, 'Organisational legitimacy beyond ethnicity? Shifting organisational logics in the struggle for immigrant rights in Los Angeles', Journal of Ethnicity and Migration Studies 42:9 (2016) 1420-1438.

101 K. Andrews and B. Edwards, 'Advocacy organisations in the US political process', Annual Review of Sociology 30:1 (2004) 479-506.

102 K. Martens, 'Non-governmental Organisations as corporatist mediator? An analysis of NGOS in the UNESCO System', Global Society 15:4 (2001) 387-404.
} 
dismissing or impeding the activities of others, as NGO-isation. ${ }^{103} \mathrm{NGO}$-isation has made it more difficult for new organisations to gain a foothold. It has also made it difficult for weak states to resist the influence of large NGOs. This crowding-out effect (organisations becoming expendable because of competing institutions) also explains the changing role of NGOS. NGOs dealing with migration issues compete with each other over money and volunteer input, but support for an alternative goal can also strengthen the NGOs' migration activities (e.g. women's rights, famine relief). The options open to NGOs depend on what IGOs and national or supranational institutions cannot or do not want to do. Over time NG Os became more intertwined with each other and with IGOS, and more similar as a result of imitation, developments under similar constraints, financial entanglement and formalised relations. ${ }^{104}$ And while this intertwining has in many cases strengthened the positions of NGOs, it has also blurred the lines between NGOS, and between NGOS and IGOS. Competition has increased because NGOS and IGOs became too similar.

\section{9}

\section{Conclusion}

In this article we sought to explain the role of NGOs in European migration governance and when and why it changed. Over time, NGOs have branched out, diversified, and increasingly worked in multiple domains. Authorities have relied on NGOs for practical and societal support. NGOs had moral authority (derived from their campaigns against trafficking, for starving children, and from their claims towards neutrality); expert authority due to their legal knowledge and access to statistics; and logistical authority because they could move goods and mobilise people. The end of the Cold War meant that a new field of operations opened up and NGOs that had been active in Western Europe became active in Eastern Europe. The lack of a strong civil society in Eastern Europe meant they could play a key role. Eventually IGOs and NGOs created a symbiosis. NGOs competed with each other and with IGOs. As IGOs' power has increased, so too has that of NGOs. The blurring of lines between

\footnotetext{
103 J. Hearn, 'The 'NGO-isation' of Kenyan society: USAID \& the restructuring of health care', Review of African Political Economy 25:75 (1998) 89-100; I. Jad, 'The NGO-isation of Arab Women's Movements', IDs Bulletin 35:4 (2004) 34-42.

104 L. Gordenker and T.G. Weiss, 'Pluralising global governance: analytical approaches and dimensions', Third World Quarterly 16:3 (1995) 357-387; H. Wieters, 'Reinventing the firm: from post-war relief to international humanitarian agency', European Review of History 23:1-2 (2016) 116-135.
} 
NGO and IGO work, representation and organisation, resulted in NGOs being further encapsulated within the government system. Some of the older NGOS became bigger and more involved, while some lost part of their influence because they were silenced.

The position of states and their activities, geopolitical power relations and national politics, societal changes, internal politics and competition and cooperation between NGOS and with IGOs all explain the changing role of NGOS in European migration governance. Based on our overview, we found that it is the competition and cooperation between NGOs and with IGOs that drives change. This relation between NGOS and with IGOs is something the literature has largely neglected. 